The American Journal of Political Science Law and Criminology

(ISSN - 2693-0803)

VOLUME 04 ISSUE 01 Pages: 66-72

SJIF IMPACT FACTOR (2020: 5. 453) (2021: 5 • 952)

OCLC - 1176274523 METADATA IF - 7.659

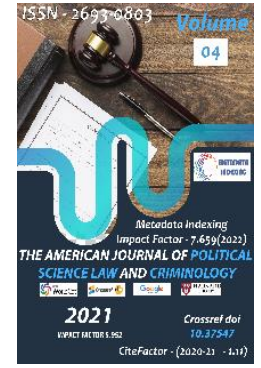

Journal Website: https://theamericanjou rnals.com/index.php/ta jpslc

Copyright: Original content from this work may be used under the terms of the creative commons attributes 4.0 licence.
Research Article

\section{ANALYSIS OF LEGISLATION ON THE PREVENTION OF JUVENILE DELINQUENCY IN DEVELOPED FOREIGN COUNTRIES}

\author{
Submission Date: January 09, 2022, Accepted Date: January 20, 2022, \\ Published Date: January 30, 2022 \\ Crossref doi: https://doi.org/10.37547/tajpslc/Volume04lssue01-11
}

Begzod Umirzakov

Doctor of Philosophy in Legal Sciences, Academy of the Ministry of Internal Affairs of the Republic of Uzbekistan

\title{
ABSTRACT
}

The article presents foreign experience in combating crime, features of juvenile delinquency and analysis of legislation of developed foreign countries aimed at preventing it, the experience of the United States of America, France, Germany, Japan and the Russian Federation aimed at preventing juvenile delinquency, guarantees of the rights of minors, supervision of minors left unattended, statistical analysis of juvenile delinquency, opinions of foreign and Uzbek scientists on the topic, opinions were expressed on the prevention of juvenile delinquency.

\section{KEYWORDS}

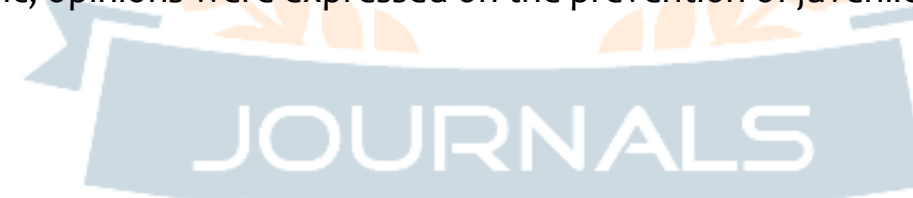

Minor, juvenile delinquency, prevention of juvenile delinquency, guarantees of the rights of minors, «Educational court», legal education program, «hotline 3919», «street teacher», minors left without parental care.

\section{INTRODUCTION}

Activities to ensure public order and security in individual States and administrative territories are provided in various ways and methods. Each state has a unique advanced experience in this area, the study and implementation of which in the system of ensuring public order and security of the country is one of the current requirements of today [13].D.V. Vasiliev believes that the study of foreign experience in the fight against crime will make it possible to determine the most important directions and ways of 
The American Journal of Political Science Law and Criminology (ISSN - 2693-0803)

VOLUME 04 ISSUE 01 Pages: 66-72

SJIF IMPACT FACTOR (2020: 5. 453) (2021: 5 • 952)

OCLC - 1176274523 METADATA IF - 7.659

development of society, to prevent the repetition of misconceptions and erroneous approaches in the process of long-term historical development of mankind [7].

The crime-fighting system of each State differs from other countries in certain, specific aspects. Studying the experience of the United States of America in analyzing the characteristics of juvenile delinquency and the legislation of developed countries aimed at preventing it is important, since it is a State with its own specific system and best practices.

In this state, a kind of regulatory framework has been formed aimed at preventing juvenile delinquency, which is reflected in the US Law "On Prevention and Judicial Proceedings of Minors" [3] (2002) is of great importance. The fact that laws concerning guarantees of the rights of minors have been codified in the United States clearly demonstrates the existence of a clear position of the state on this issue. In particular, the Federal Code on Juvenile Delinquency [2] establishes mechanisms for resolving crimes and offenses committed by minors in court.

In the USA, 1.5 thousand centers for victims of domestic violence, individual homes have been organized, women, elderly people, minors who have been victims of domestic violence, who have been beaten, humiliated, and harassed by family members in their home 5 turn to these centers [19].

Noteworthy is the practice that has developed in the United States in the field of juvenile delinquency prevention and the formation of legal awareness and legal culture of minors, school curricula include teaching the basics of the justice system. For example, in Arizona, training is conducted in the form of a «training court». The roles of a policeman, a lawyer, a witness, a journalist, and a judge are distributed among the pupils. The role of the accused in this is played by a policeman who is not familiar to schoolchildren. The game is managed by an employee and a school teacher[18].

Special attention is paid to the prevention of juvenile delinquency in Virginia Beach. A special program has been implemented here, within the framework of which a special 3-week course will be held for 4 th grade students, including 6 topics: law and crime, home security, shoplifting, robbery and personal security, after which students will be awarded certificates and badges. The peculiarity of the course is that classes are conducted by police officers as a factor influencing the behavior of students. The authors of the program believe that their main goal is to teach a child from an early age to correctly assess social phenomena, avoid possible potential danger, and form skills of interaction with the police [11].

The legal education program developed by the US law enforcement agencies in Florida and implemented in the public and private sectors also deserves attention. This program for students of grades 7-8 is aimed at forming knowledge about the place of the individual in the value system of society, about the duties of a citizen and the basics of criminal law, about the punishment that awaits violators of law and order. It can be seen that all the programs under study are specifically aimed at stimulating the legal awareness and legal culture of minors, thereby preventing crime [12].

In France, the Law "On the Prevention of Violence against Children» (2007) is in force. When cases of child abuse are detected, it is necessary to immediately contact State and law enforcement agencies. Persons who knowingly did not report this information to law enforcement agencies can be sentenced to imprisonment for up to 3 years or a fine of 45 thousand 
The American Journal of Political Science Law and Criminology

(ISSN - 2693-0803)

VOLUME 04 ISSUE 01 Pages: 66-72

SJIF IMPACT FACTOR (2020: 5. 453) (2021: 5. 952)

OCLC - 1176274523 METADATA IF - 7.659

Crossref do

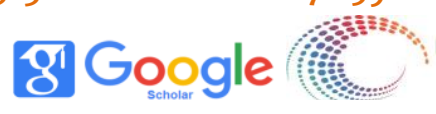

metapata

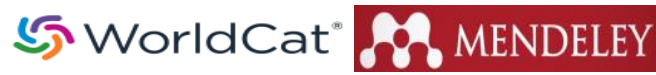

Publisher: The USA Journals

euros [4]. In addition, in France there are a number of centers to which women or minors can apply, and there is a practice of calling the "hotline 3919" to contact them. If the family situation requires it, the victim of violence is invited to go and live in organized houses [18].

In Germany, special attention is paid to the peculiarities of juvenile delinquency and their social protection in its prevention, and it can be seen that the legal mechanisms of this system are well-established. In particular, this was done in accordance with the main purpose of the Law «On Assistance to Children and Youth (Kinder - und Jugendhilfegesetz - KJHG, §11)» [15], which states: «Help the child before he falls into the well!» 11 it is not difficult to understand that this is also a slogan. In accordance with the law, a system of organizations and institutions working with children in difficult life situations has been established, the results of which are evaluated on the basis of the volume and scale of assistance provided to families. This system is engaged in providing socio-psychological and sociopedagogical assistance [10].

While the service responsible for ensuring public order and security in Germany is called the «Public Order Police» and each region of the country has its own laws and departmental acts, the activities of the public order police are the same in all countries, as well as supervision of minors left without supervision [20].

The system of social assistance services for minors includes a separate direction "street teacher» [22], which differs significantly from the practice of units for working with minors existing in the police system of most countries (including Uzbekistan). In particular, it solves the problem of achieving the effectiveness of crime prevention based on a programmatic approach. At the same time, the implemented programs provide for the solution of current organizational issues using the forces of citizens on the basis of minimizing the activities of the police [17]. The implementation of projects aimed at preventing the commission of terrorism, religious extremism and other serious crimes in this State plays an important role in preventing the ideological influence of religious movements on minors and their commission of criminal acts.

In particular, one of such programs is «Exit», whose activities are funded by private foundations. This group helps the population (mainly vulnerable youth) to move, find a job and even change their personal data as a witness to a crime. Over the past 10 years, more than 300 people have benefited from the support of the Exit 16 program [6]. Another important project being implemented in the country is the «Competitor for Democracy - networks against right-wing extremism» program, the main task of which is to provide professional advice aimed at expanding and developing children's skills to get out of extreme (problematic) situations and fight them [24]. One of the main directions of the program is also to help prevent children from being involved in the activities of non-governmental groups and turning them into users of «forbidden zones» in social networks [25].

It can be seen that preventive measures under these programs have yielded results. In particular, Germany ranks sixth among the countries that achieved a reduction in crime in 2017 by ensuring crime prevention, after the USA (48.7\%), Italy (44.6\%), France (43.6\%), Great Britain (41.1\%), Spain (32.2\%), where the crime reduction was $32.0 \%$ during the year [9].

In Japan, much attention is paid to cooperation with the public in the prevention of juvenile delinquency, the societies «Brothers and Sisters», «Parents and Teachers", self-government committees and points of contact with the police are equal subjects of 
The American Journal of Political Science Law and Criminology

(ISSN - 2693-0803)

VOLUME 04 ISSUE 01 Pages: 66-72

SJIF IMPACT FACTOR (2020: 5. 453) (2021: 5. 952)

OCLC - 1176274523 METADATA IF - 7.659

cooperation in this direction. The society «Brothers and Sisters", which took its place in law enforcement, prevention of juvenile delinquency, was first established by students in Kyoto in 1947. There are currently thousands of members of the society, and hundreds of local communities operate throughout Japan [16]. The Society of Parents and Teachers, which helps the police in ensuring the prevention of juvenile delinquency, today has its place in every school. The activities of this society at the national level are coordinated by the National Council of the Society of Parents and Teachers [14].

The Russian Federation is also one of the States in which the specifics of juvenile delinquency and a kind of system for its prevention have been created. Positive trends in the organization of activities in this direction have been traced since 2000, when it was concluded that a reliable, effective and safe system of protecting individuals, society and the state from criminal encroachments would not be created in the life of Russia.

The analysis shows that the main principles of the crime prevention system in this state are: improvement of the regulatory framework in this area; systematic implementation of preventive work among minors; social adaptation of persons released from prison, as well as persons who do not have a permanent job or place of residence; increasing the role of civil society institutions in ensuring law and order.

The conducted studies allow us to conclude that a sufficient regulatory framework has been created in this country to regulate the prevention of juvenile delinquency. The main document fixing the legal status of subjects of juvenile delinquency prevention is the Law of the Russian Federation "On the basics of the system of prevention of neglect and juvenile delinquency» (1999). It defines the tasks and functions, powers, main areas of activity and mechanisms for ensuring the activities of entities responsible for the prevention of juvenile delinquency.

The Decree of the President of the Russian Federation «National Strategy of Actions in the interests of the Child» for 2012-2017 (2012) defines the main directions and objectives of state policy aimed at the interests of the child. The need for this document is explained by the discrepancy between the activities of juvenile affairs commissions and the status of the child rights protection system today, which provides for the coordination of the activities of organizations and bodies that ensure the prevention of neglect and juvenile delinquency.

However, statistical data indicate unsatisfactory results of activity in the analyzed direction. Thus, according to the Prosecutor General's Office of Russia, in 2013 in Moscow the rate of crimes committed by teenagers increased by $24.1 \%$. At the same time, the number of thefts, robberies and robberies committed by minors increased by $40 \%$ [21].

It is from this point of view that the main attention is paid to the problems of ensuring the interaction of internal affairs bodies, interdepartmental commissions for minors, medical and preventive institutions, public education, cultural and educational institutions and civil society institutions in order to increase the effectiveness of the prevention of uncontrolled and delinquency among minors.

In accordance with the requirements of the Law of the Russian Federation «On the basics of the system of prevention of neglect and delinquency among minors» (1999), with children who are registered at school or are in the «risk group», the following is carried out: social certification of classes at the beginning of the school year (creating a database of students, compiling 
The American Journal of Political Science Law and Criminology (ISSN - 2693-0803)

VOLUME 04 ISSUE 01 Pages: 66-72

SJIF IMPACT FACTOR (2020: 5 - 453) (2021: 5. 952)

OCLC - 1176274523 METADATA IF - 7.659

lists of any registered children, conducting pedagogical diagnostic work by the class teacher and teacherspsychologists aimed at studying their personal and family problems; an observation diary is kept, which records the daily attendance of students, the offenses they commit and the measures taken against them, as well as the results of preventive measures; teenagers who are prone to committing offenses are identified, their extracurricular activities are monitored (involvement in various circles and classes); in order to ensure attendance and effective control of the educational process, raids are carried out on the places of residence of students with the participation of the school administration and classroom teachers; preventive councils have been established in schools, where individual and group conversations are held with students (their parents) who have difficulties in mastering subjects and have behavioral problems; preventive conversations and propaganda work are conducted with the participation of representatives of the local police on various topics such as «School is the territory of law», «Prevention of offenses», «What is law?», «Do you know your rights?» [23].

The experience of developed countries in this area shows that the effectiveness of crime prevention directly depends on the special programs and projects implemented in them. Programs such as «neighborhood watch», «crimes toppers», «Crime prevention through vironment design (broken window)», «Safety City» give positive results in practice [8].

The implementation of such programs and projects in practice will undoubtedly give a positive result in the practice of all countries. In this regard, at the initiative of the President of our country Shavkat Mirziyoyev, the hardware and software complexes "Safe Capital», "Safe City», «Safe Tourism» were put into operation.
We believe that based on the study of the experience of the above-mentioned states, it is necessary to develop and adopt a «Concept for the development of prevention of neglect and juvenile delinquency» [1] and a roadmap for its implementation in the Republic of Uzbekistan for the long term (2021-2025). We believe that the adoption of this concept by 2025 will not only reduce the overall dynamics and level of juvenile delinquency, but also significantly reduce the structure of juvenile delinquency, and at the same time ensure a high level of protection of the rights and legitimate interests of minors.

In general, the peculiarities of juvenile delinquency and the peculiarities of the experience of developed foreign countries in its prevention are: firstly, in the direct dependence of the effectiveness of crime prevention on the special programs and projects implemented in them; secondly, in the codification of legal mechanisms to guarantee the rights of minors; thirdly, in the recognition of «juvenile law» as an independent branch of law; fourth, the increase in the level of protection of the rights of minors is expressed in the introduction of the juvenile justice system.

\section{REFERENCES}

1. «Ўзбекистон Республикасида вояга етмаганлар ўртасида назоратсизлик ва хуқуқбузарликлар профилактикасини 2025 йилгача такомиллаштириш концепцияси» лойихаси. Диссертацияга илова қилинган.

2. Federal juvenile delinquency code // [Электрон манба]: https://www.justice.gov/jm/criminalresource-manual-117-federal-juvenile-

delinquency-code (мурожаат вақти: 08.06.2019 й.).

3. Juvenile Justice and Delinquency Prevention Act of 2002 // [Электрон манба]: https://www.ojjdp.gov/about/ 
The American Journal of Political Science Law and Criminology

(ISSN - 2693-0803)

VOLUME 04 ISSUE 01 Pages: 66-72

SJIF IMPACT FACTOR (2020: 5. 453) (2021: 5. 952)

OCLC - 1176274523 METADATA IF - 7.659

ojjdpact2002.html (мурожаат вақти: 12.11.2019 й.).

4. Астанов И. Оиладаги зўравонликнинг сабаб ва шароитлари, профилактикаси хамда хорижий тажриба // Оилалардаги зўравонликларнинг сабаб ва шароитлари, профилактикаси хамда хориж тажриба: республика илмий-амалий конференцияси матермаллари. - Т.: Ўзбекистон Республикаси ИИВ Академияси, 2017. - Б. 51.

5. Ахъядов Э.С. Отечественный и зарубежный опыт профилактики безнадзорности и правонарушений несовершеннолетних // «Молодой учёный». - 2016. - № 2 (106). - С. 659.

6. Большова Н.Н. Молодежная политика вЕС: Роль образования впротиводействии проявления экстремизма (пример Германии) // [Электрон манба]: https://mgimo.ru/files2/z11_2014/Molodezhnay a-politika-v-EU-rol-obrazovaniya-v-

protivodeystvii-proyavleniy-ekstremizma.pdf (мурожаат қати: 11.01.2020 й.).

7. Васильев В.Д. Концепции организации деятельности полиции и возможности их использования в отечественной практике: По материалам США и некоторых стран Западной Европы: Автореф. Аис. ... канд. юрид. наук. - М., 2005.

8. Головкина А., Потоцкий Н. Зарубежный опыт разработки программ профилактики правонарушений // [Электрон манба]: https://pandia.ru/text/78/094/83215.php (мурожаат вақти: 18.01.2020 й.).

9. Гордеев А.Ю. К вопросу о положительном опыте предупрежденияпреступлений в зарубежных странах // Matters of Russian and International Law. - 2017. - Vol. 7. - P. 116 (115121).
10. Ғофуров Ш.Р. Уюшмаган ёшлар ўртасида хуқуқбузарликлар профилактикасини такомиллаштириш (Ички ишлар органлари фаолияти мисолида): : юридик фанлар бўйича фалсафа доктори (PhD)диссертацияси - Т., 2019. - Б. 111.

11. Гусейнов А.Б. Профилактика правонарушений несовершеннолетних за рубежом // [Электрон манба]: https://www.twirpx.com/file/1172281/ (мурожаат вақти: 17.01.2020 й.).

12. Дородонова Д.Н. Регулирование вопросов по организации профилактики правонарушений несовершеннолетних в зарубежном законодательстве: история и современность // Вестник Саратовской государственной юридической академии. 2017. - № 5 (118). - С. 195.

13. Зиёдуллаев М.3. Ички ишлар органларининг таянч пунктларини бошқаришни такомиллаштириш: юрид. фан. А-ри. ... дис. Т., 2019. - 294 б. Б. 217.

14. Зиёдуллаев М.3. Ички ишлар органларининг таянч пунктларини бошқаришни такомиллаштириш: юрид. фан. А-ри. ... дис. Т., 2019. - 294 б. Б. 233.

15. Калинкина М.Ю. Государственная политика Германии в сфере социальной и молодёжной работы // Образование за рубежом. - 2015. - № 5. - С. 118, 121.

16. Кан Уэда. Преступность и криминология в современной Японии / Пер. с японск. О.А. Белявской. - М.: Прогресс, 1989. - С. 161.

17. Мороков И.Р. Участие представителей гражданского общества в профилактике безнадзорности и правонарушений несовершеннолетних: зарубежный опыт // Шестая ежегодная конференция кафедры 
The American Journal of Political Science Law and Criminology

(ISSN - 2693-0803)

VOLUME 04 ISSUE 01 Pages: 66-72

SJIF IMPACT FACTOR (2020: 5. 453) (2021: 5 • 952)

OCLC - 1176274523 METADATA IF - 7.659

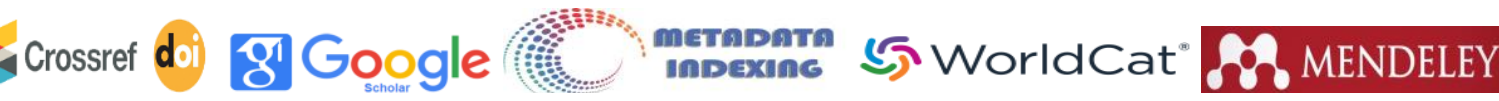

24. Хайнц Р., Бюринг О. Молодежь вцентре

Истории науки и техники - Екатеринбург: УМЦ УПИ, 2016. - С. 267.

18. Муродов А.Ш. Ички ишлар органларининг оиладаги зўравонлик билан боғлиқ хуқуқбузарликлар профилактикасини такомиллаштириш: юридик фанлар бўйича фалсафа доктори (PhD)диссертацияси - T., 2019. - Б. 100.

19. Муродов А.Ш. Ички ишлар органларининг оиладаги зўравонлик билан боғлиқ хуқуқбузарликлар профилактикасини такомиллаштириш: юридик фанлар бўйича фалсафа доктори (PhD)диссертацияси - T., 2019. - Б. 98.

20. Полиция зарубежных стран: система организации и опыт профессиональной подгатовки кадров: Учебное пособие / Якубов А.С., Асямов С.В., Таджиев А.А., Миразов А.М. - Т., 2010. - С. 323.

21. Рекомендации Общественной палаты РФ на тему «Состояние и профилактика преступности среди несовершеннолетних» // [Электрон манба]: http: // inbalashikha.ru / novosti / obshchestvo / rekomendaciiobshchestvennoy-palaty-rf-na-temu-

sostoyanie-i-profilaktika-prestupnosti-sredi-

nesovershennoletnih (мурожаат вақти: 03.09.2019).

22. Социальная работа в Германии // [Электрон манба]:

work.ru/article/152(мурожаат 11.01.2020 й.).

23. Федеральный закон от 24 июня 1999 г. N 120Ф3 «Об основах системы профилактики безнадзорности и правонарушений несовершеннолетних» (с изменениями и дополнениями) // [Электрон манба]: http://base.garant.ru/12116087/ (мурожаат вақти: 05.09.2019). внимания // [Электрон манба]: https://moluch.ru/archive/106/25303/(мурожа ат қати: 11.01.2020 й.).

25. Чекалина А.А.Превенция экстремизма молодежи: опыт Великобритании //[Электрон манба]: http://cyberleninka.ru/article/n/preventsiyaekstremizma-molodezhi-opyt-velikobritanii (мурожаат вақти:11.01.2020 й.). 